\title{
Spice bioactives in edible packaging
}

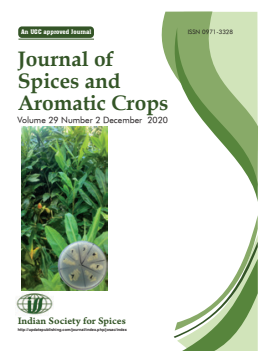

\author{
K Ravi, K Goyal, S Priyadarshi \& M M Naidu* \\ Department of Spices \& Flavour Sciences, \\ CSIR-Central Food Technological Research Institute, Mysuru-570 020, Karnataka. \\ *E-mail: mmnaidu@cftri.res.in
}

Received 04 October 2020; Revised 08 December 2020; Accepted 18 December 2020

\begin{abstract}
Edible packaging received significant attention in recent years. The main advantage of edible packaging over synthetic packaging is that they are environment friendly. The material used in edible packaging (lipids, polysaccharides, proteins) is generally recognized as safe and it acts as a barrier to gases, light and moisture. Spices have been traditionally used for its medicinal value. Spice extract or its essential oil possesses various bioactive compounds which are known for their antioxidant and antimicrobial property. Incorporation of spice extract or its essential oil into edible packaging exerts antimicrobial activity against the food pathogens thus preventing food spoilage and enhances the shelf-life and also increases the nutritional value of the final product. Antioxidant properties of spices retard the lipid oxidation. Dietary allergy and intolerance are also associated with packaging material and spices. Because of the high cost of film-forming material, scaling-up of edible packaging has remained a problem.
\end{abstract}

Keywords: antimicrobial activity, bioactive compound, edible coating, edible film, spice constituents, spice essential oil

\section{Introduction}

Global consumption of plastic is about 285 million metric tons (MMT) per year and India contributes about 12.8 MMT annually. In India, more than $40 \%$ of packaging needs are catered by plastics (FICCI 2016). Every year plastic wastage of about 8 MMT enters the ocean and it takes 400 years for their breakdown which pollute the cities and harm animal life. To overcome these environmental effects companies are trying to substitute edible packaging as an alternative for plastic packaging (Spencer 2018). Food and pharmaceutical industries have recognized edible packaging as an alternative to plastic packaging. Environmental Protection Agency reported that containers and packaging of food contribute about $30.2 \%$ of household waste. Milk proteins, vitamins, proteins and 
probiotics are the raw materials used for edible packaging which acts as a barrier for gaseous concentration thereby preventing food products from contamination (Mamtani 2017). The primary functions of edible packaging are represented in Fig. 1.

The two main classifications of edible packaging are edible coating and edible film. The edible coating is applied as a skinny layer on the food products which is in direct contact with the food. A thin layer of edible material in which the food is being packed is known as edible films. Edible packaging helps in minimizing environmental pollution by reducing plastic waste (Ghosh et al. 2020).

To achieve better organoleptic characteristic and increased shelf-life, spices have been used as a food additive. Reduction in lipid oxidation and antimicrobial activity of the spices is due to the presence of flavonoids, terpenoids and phenolic compounds (Negi 2012; Tajkarimi 2010). To improve the stability of oxidation-sensitive food, antioxidants have been incorporated in the edible packaging material, whereas incorporation of synthetic antioxidants exert toxicological effects. Hence, natural antioxidants extracted from spices and its essential oils (EOs) can be recommended (Silva-Weiss 2013). Spices also act as a potential alternative to food synthetic preservatives (Gomez-Estaca et al. 2014). Spices can be incorporated in the form of powder/aqueous extracts/EOs into natural or synthetic polymer matrices of edible packaging. Avila-Sosa et al. (2012) noted that an edible film incorporated with essential oil provides the microbiological stability to the food and it can extend the shelf-life of the food.

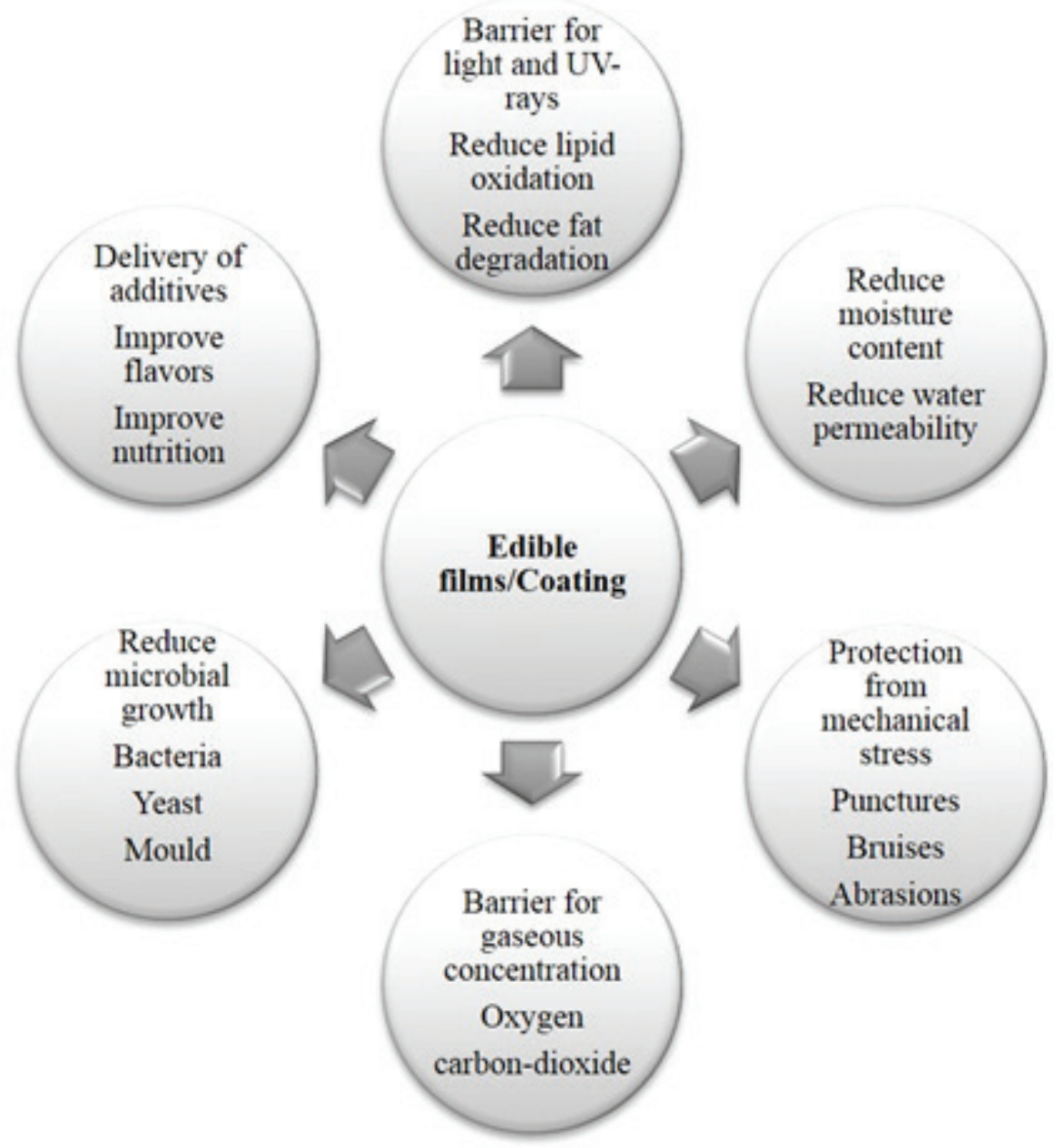

Fig. 1. Functions of edible packaging (Ghosh et al. 2020) 
Incorporation of essential oil helps to minimize the water vapour pressure (WVP) of the edible film (Tongnuanchan et al. 2013).

\section{Materials used in edible packaging}

\section{Polysaccharides based edible packaging}

In the edible packaging, plastic is replaced by carrageenan, starch, alginate, pectin and xanthan gum (Espitia et al. 2014). Chitosan films are resistant to fat, oil and oxygen but they are highly permeable to moisture (Nayik et al. 2015). Almasi et al. (2010) reported that carboxy-methyl cellulose (CMC) has an excellent film-forming property with a water-soluble polymer. Starch-based films are colourless, flavourless and tasteless (Skurtys et al. 2011). Pectin films are effective in the protection of low moisture food (Liu et al. 2007). Pectin films are highly suitable for the packaging of fruits and vegetables (Valdes et al. 2015a). Fruits coated with arabic or almond gum resulted in a significant decrease in the ethylene production and respiration rate (Mahfoudhi \& Hamdi 2015). Addition of calcium in alginate films decreases the permeability of water vapour (Olivasa et al. 2008). Carrageenan films prevent the superficial dehydration in meat, poultry, fish and oily foods (Karbowiak et al. 2006). Pullulan is highly capable of preparing the odourless, colourless, tasteless and heat-sealable edible film. However, pullulan is water permeable, low oil and oxygen permeable (Diab et al. 2001; Kanmani et al. 2013). Gellan films are hard and brittle (Lee et al. 2004). Fresh-cut vegetables coated with gellan gum have better quality and shelf-life (Dalanche et al. 2016). Quality and shelf-life of fresh-cut fruits were improved by applying a xanthan gumbased edible coating (Freitas et al. 2013).

\section{Lipid-based edible coatings}

The edible film made up of lipids provides gloss, reduction in moisture loss and reduced cost (Huber \& Embuscado 2009). Pork meat hamburger coated with sunflower oil enhanced the quality of the food (Vargas et al. 2011). Hassani et al. (2012) observed that rice bran oil extended the shelf-life of kiwi fruit with good taste, colour, and firmness. Fresh cut fruits coated with candelilla wax extended the shelf-life of fruits. It also increased the antioxidant potential and nutritional quality of the fruits (Saucedo-Pompa et al. 2007). Plasticizer increases the flexibility and strength of the edible packaging material (Han 2014). Addition of diverse plasticizers to edible packaging material increases the moisture content and thickness of the film (Razavi et al. 2015).

\section{Protein-based edible packaging}

Protein films have better mechanical properties than polysaccharides (Bourtoom 2008). Milk protein acts as a good carrier for antioxidant and antimicrobial agents. Milk protein forms flexible, flavourless and transparent films (Wagh et al. 2014; Sabato et al. 2001). Fabra et al. (2010) reported that sodium caseinate films have a good optical property and tensile property. Oses et al. (2009) noted that whey protein films (90\% protein) are impermeable to oxygen at a low/intermediate relative humidity. While making the edible film $50 \%$ of calcium caseinate is replaced by whey protein isolate without reducing the puncture strength of the film. In the meat industry, collagen is used as an edible film for meat product cooking (Jeevahan et al. 2017). Jongjareonrak et al. (2006) noted that gelatin films with increased protein content exhibit increased film thickness and mechanical properties. Denavi et al. (2009) described that the edible film of soy protein is more flexible than other protein films from plant sources.

\section{Spice bioactives and their antimicrobial activities}

The addition of bioactive compound directly to food packaging material exerts antimicrobial activity against the targeted microorganisms and prevent the oxidative degradation which results in the shelf-life extension of the food (Manzanarez-Lopez et al. 2011). Bioactive compounds from various spices and their antimicrobial activity are given in Table 1 . Incorporation of the bioactive compound in packaging material altered the thermal, morphological and mechanical property of the edible film. Ramos et al. (2014) noted that bioactive compounds of spices act against the lipid auto-oxidation in the food. 


\section{Basil}

The main constituent of basil essential oil (Ocimum basilicum L.) is linalool, followed by epi-a-cadinol, $\alpha$-bergamotene and c-cadinene (Hussain et al. 2008). Lee et al. (2005) noted that eugenol and 4-allylphenol as the main constituents responsible for the antioxidant activity of the volatile extract of basil. Antimicrobial property of basil essential oil is mainly due to the presence of higher content of linalool.

\section{Cinnamon}

Vallverdu-Queralt et al. (2014) noted that the major bioactive compounds of cinnamon (Cinnamomum spp.) include cinnamic acid, cinnamyl aldehydes, protocatechuic acid, rutin, quercetin and epicatechin. Cinnamaldehyde is reported to exhibit antibacterial activity against Staphylococcus aureus, Bacillus cereus, Escherichia coli, Salmonella anatum and Listeria monocytogenes (Shan et al. 2007). El-Baroty et al. (2010) reported that cinnamaldehyde and eugenol are the most active antioxidant and antibacterial compounds in the cinnamon bark oil.

\section{Clove}

Clove (Syzygium aromaticum) contains various antioxidant substances and phenolic components which can potentially be used in the food products (Zengin \& Baysal 2015). Eugenol is the compound mainly responsible for the antioxidant property of the clove extract. Bioactive compounds of clove include eugenol, $\alpha$-cubebene, iso-eugenitol, $\alpha$-copaene, $\beta$-caryophyllene, $\beta$-bipinene (Harlina et al. 2018). Lee \& Shibamoto (2001) reported that the other major constituents of clove in addition to eugenol are eugenol acetate and $\beta$-caryophyllene. Eugenol in clove delays the lipid oxidation activity (Krishnan et al. 2014).

\section{Coriander}

The main bioactive compounds of coriander (Coriandrum sativum L.) are quercetin, kaempferol, apigenin and rhamnetin. Basilico \& Basilico (1999) reported that coriander essential oil exhibit inhibitory effects on the mycelial growth and toxic substances produced by Aspergillus ochraceus. Meena \& Sethi (1994) reported that coriander essential oil has the potential to control Mycoderma sp., Lactobacillus acidophilus, Saccharomyces cerevisiae, Aspergillus niger and Bacillus cereus. Caffeic acid, a phenolic compound in coriander is responsible for its antioxidant activity (Meloa et al. 2005). A new molecule (Heneicos-1-ene) responsible for radical scavenging activity was identified in coriander foliage and reported to exhibit comparable radical scavenging activity with BHA at 200 ppm level (Priyadarshi et al. 2018).

\section{Cumin}

Alcoholic extract of cumin (Cuminum cyminum L.) and its essential oil shown antimicrobial activity against Klebsiella pneumoniae ATCC 13883 (Derakhshan et al. 2007). 3-caren-10-al, cuminal and 2-caren-10-al are the bioactive compounds involved in the antifungal activity of cumin essential oil. Chemovar of cumin is responsible for the higher antioxidant activity of cumin essential oil (Ghasemi et al. 2018).

\section{Fennel}

Trans-anethole is the main component of fennel (Foeniculum vulgare Mill) followed by estragole, limonene and fenchone (Diao et al. 2014). Antioxidant and antimicrobial activity of fennel is mostly due to the higher concentration of trans-anethole (Shahat et al. 2011; Senatore et al. 2013). Fennel essential oil was reported to possess antifungal activity by reducing the growth of mycelium and germination of Sclerotinia sclerotiorum (Soylu et al. 2007).

\section{Garlic}

The major bioactive compounds of garlic (Allium sativum L.) are diallyl disulfide, S-allyl-cysteine, diallyl thiosulfonate (allicin), E/Z-ajoene, diallyl sulfide, S-allyl-cysteine sulfoxide (alliin) and diallyl trisulfide (Kodera et al. 2017; Mansingh et al. 2018; Yoo et al. 2014). The major phenolic compounds found in garlic are rutin, quercetin, pyrogallol, protocatechuic acid, gallic acid and $\beta$-resorcylic acid (Nagella et al. 2014). Biological activity of the garlic is mainly due to organosulfur compound allicin. Allicin has 


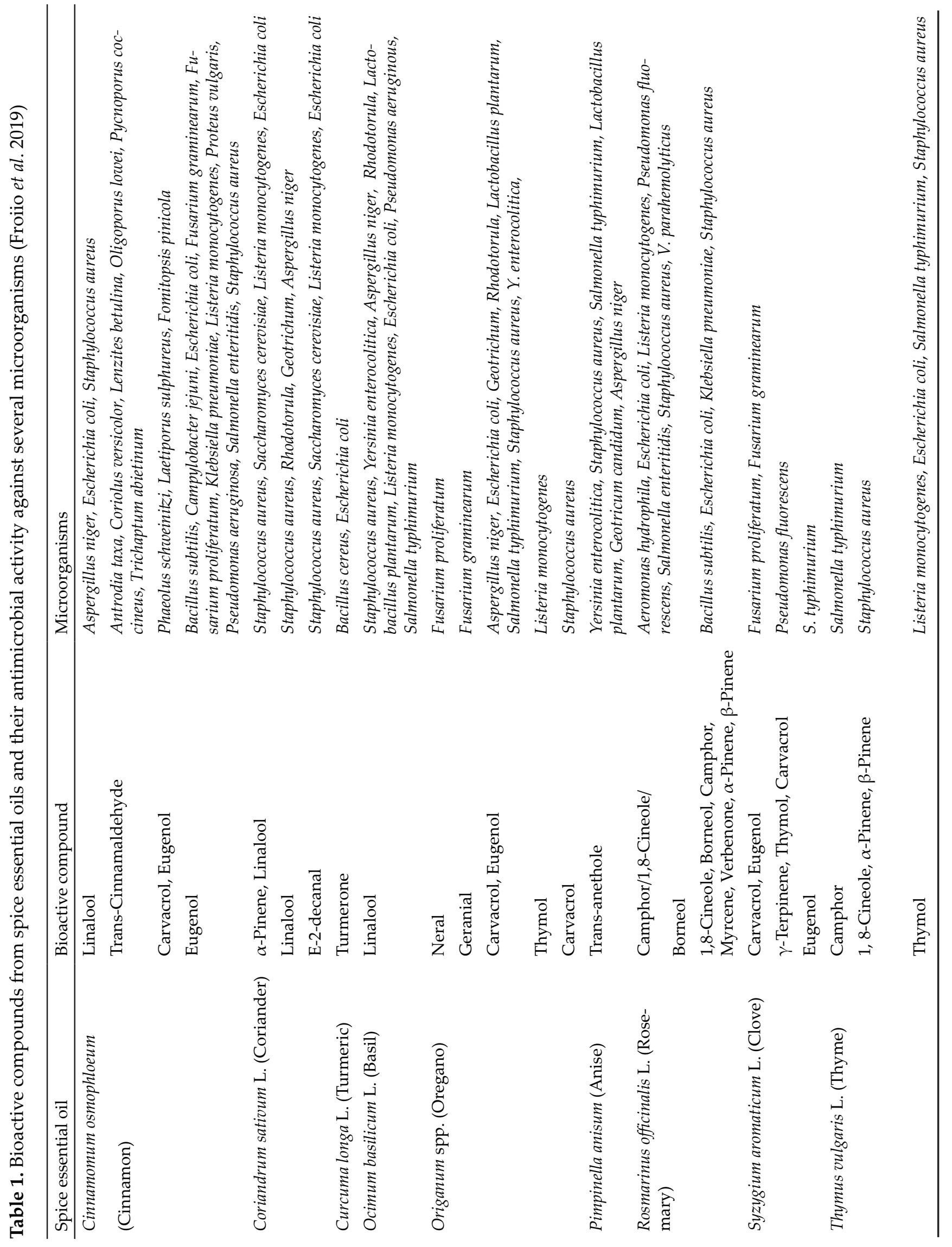


antimicrobial property and also prevents lipid oxidation (Lanzotti et al. 2014).

\section{Ginger}

Gingerols, paradols and shogaols are the major phenolic compounds present in the ginger (Zingiber officinale) (Prasad \& Tyagi 2015). The most active antibacterial components in ginger rhizome oil are $\beta$-sesquiphellandrene, caryophyllene and zingiberene (El-Baroty et al. 2010). Manasa et al. (2013) reported that 6-gingerol is the major bioactive compound present in the ginger. Antimicrobial properties of the ginger are desirable for edible packaging.

\section{Nutmeg}

Arshad et al. (2020) reported that the major compounds in nutmeg (Myristica fragrans Houtt) include $\alpha$-terpinolene, $\beta$-pinene, $\gamma$-terpene, $\alpha$-longipinene and safrole. Nutmeg oleoresin contains considerable amounts of $\alpha$-terpineol, $\alpha$-pinene, carane, myristicin and limonene. Nutmeg is reported to exhibit antibacterial and antifungal activity against Staphylococcus aureus and Aspergillus niger (Gupta et al. 2013). Nakai et al. (2003) reported that the antioxidant property of the nutmeg is due to catechol produced by the nutmeg lignan after absorption.

\section{Oregano}

Origanum essential oil contains $\gamma$-terpinene, $p$-cymene, thymol and carvacrol. The essential oil of oregano also has antimicrobial, antioxidant, antiviral and anticancer activity (Beltran et al. 2016; Kaefer et al. 2008; Guldiken et al. 2018). Kavoosi et al. (2013) described carvacrol incorporated gelatin films exhibited an excellent antioxidant property and antibacterial property against both gram-negative and gram-positive bacteria.

\section{Rosemary}

The rosemary extract (Rosmarinus officinalis L.) is used as a natural food antioxidant in pork sausage, large yellow croaker and chicken (Georgantelis et al. 2007; Bolumar et al. 2011; Li et al. 2012). Carnosol, ursolic acid, carnosic acid, rosmaridiphenol and rosmanol are the phenolic diterpenes responsible for the antioxidant property of rosemary extract (Georgantelis et al. 2007).

\section{Star anise}

Star anise (Illicium verum) has various beneficial functions such as antioxidant, antimicrobial and insecticidal activities (Zhang et al. 2018). Trans-anethole, estragole, and limonene are responsible for the antimicrobial properties of star anise essential oil (Wang et al. 2011). Therefore, star anise essential oil has the potential to be used as an alternative to synthetic compounds as a natural antimicrobial in edible food packaging.

\section{Tarragon}

Chaleshtori et al. (2013) reported that the major bioactive compounds in tarragon (Artemisia dracunculus) are methyl chavicol, transocimene, $\mathrm{z}$ - $\beta$-ocimene, limonene and $\alpha$-pinene. Antioxidant activity of tarragon essential oil is due to the high level of methyl chavicol. Ayoughi et al. (2011) reported that linalool, limonene, spathulenol and eugenol are the compounds associated with the antioxidant activity of tarragon essential oil. Behbahani et al. (2017) stated that linalool is responsible for the antibacterial and antifungal activity of tarragon essential oil.

\section{Thyme}

The essential oil from thyme (Thymus vulgaris L.) has a higher content of thymol and carvacrol, which is responsible for its antioxidative and antimicrobial properties (Marino et al. 1999; Sacchetti et al. 2005). Burt et al. (2005) reported that carvacrol and thymol in thyme essential oil exhibited favourable bactericidal and bacteriostatic properties. Thyme essential oil possesses an antagonistic effect against Botryodiplodia theobromae Pat. and Colletotrichum gloeosporioides Penz.

\section{Essential oil and their constituents in edible packaging}

Spice extracts or its essential oils are reported to exhibit a broad spectrum of antimicrobial 
activities which make them a suitable candidate for edible packaging. Table 2 shows various spice constituents which are generally used in edible packaging and the use of spice essential oils as a natural antimicrobial in edible packaging of food is given in Table 3 .

\section{Clove and Cinnamon essential oil}

Spice (S. aromaticum and C. cassia) incorporated edible film was found to inhibit the growth of the microbes through the diffusion of cinnamaldehyde and eugenol. Thus, it extended the shelf-life and was effective in controlling the lipid and protein oxidation in chicken meat (Chandra 2019). Corn starch film incorporated with clove and cinnamon essential oil exhibited antimicrobial activity against Salmonella typhimurium and Lactococcus lactis in raw beef. Eugenol in clove essential oil is identified as the most active antimicrobial component which resulted in a reduction in lipid oxidation (Radhakrishnan et al. 2015). Tamarind seed starch film incorporated with a spice mix of $S$. aromaticum and $C$. cassia has antioxidant and antibacterial properties. Hence, it can be used as good packaging material for food products (Chandra et al. 2016). Edible film supplemented with $S$. aromaticum (clove) and C. cassia (cinnamon) exhibited significant release of active compound about $42-51 \%$ for cinnamaldehyde and $38-48 \%$ for eugenol into mutton at the storage temperatures of $4-15^{\circ} \mathrm{C}$. Cinnamaldehyde and eugenol diffusion increased the shelf-life of meat by one week at a storage temperature of $10^{\circ} \mathrm{C}$ and three weeks at a storage temperature of $4^{\circ} \mathrm{C}$ (Chandra et al. 2017).

Fish gelatin incorporated with cinnamon essential oil provides the flexible film with decreased water solubility and water vapour permeability (Salgado et al. 2013; Bahram et al. 2014; Teixeira et al. 2014; Wu et al. 2015). The composite film consisting of potato dextrose agar medium combined with gum arabic and cinnamon oil prevented the postharvest anthracnose in the tropical fruits (papaya and banana) (Maqbool et al. 2011). Apple based films with cinnamon, allspice and clove bud oils exhibited antimicrobial activity against Salmonella enterica, Escherichia coli O157:H7 and Listeria monocytogenes (Du et al. 2009).

\section{Clove and Oregano essential oil}

The edible film incorporated with $0.5 \%(\mathrm{v} / \mathrm{v})$ of clove and oregano oil extended the shelf-life of paneer by 4 days at $4 \pm 1^{\circ} \mathrm{C}$. Paneer packed in oregano essential oil-treated edible film showed more significant and desirable value for consumption than paneer sample packed in edible film treated with essential oil of clove (Karunamay et al. 2020).

\section{Curcumin}

Curcumin nano emulsion loaded gelatin composite film exhibited antimicrobial activity against Escherichia coli and Salmonella typhimurium in fresh broiler meat. Thus, the film extended the shelf-life of fresh broiler meat up to17 days (Khan et al. 2020).

Curcumin nano emulsion based pectin coating fused with cinnamon and garlic essential oils displayed the lowest total plate count (TPC), psychrophilic bacteria, yeast and mould growth in chilled chicken fillets. Reduction in microbial spoilage increased shelf-life of chicken fillets up to 12 days (Abdou et al. 2018).

\section{Fennel extract}

Guar gum-based edible coating fused with ethanolic and methanolic extract of fennel extended the shelf-life of lemons up to 180 days at $10^{\circ} \mathrm{C}(85 \%$ relative humidity) without any loss in phytochemical components and also delayed ripening process in the lemons (Naeem et al. 2019).

\section{Garlic and pepper powder}

Whey protein-based edible film fused with garlic and pepper powders displayed improved mechanical and barrier properties. At the end of the storage test, allicin $(81 \%)$ and piperine $(37 \%)$ was retained in the spiced film (Ket-On et al. 2016).

\section{Garlic/Oregano and ginger essential oil}

Achira starch-based edible coating containing garlic/oregano oils on double cream cheese 


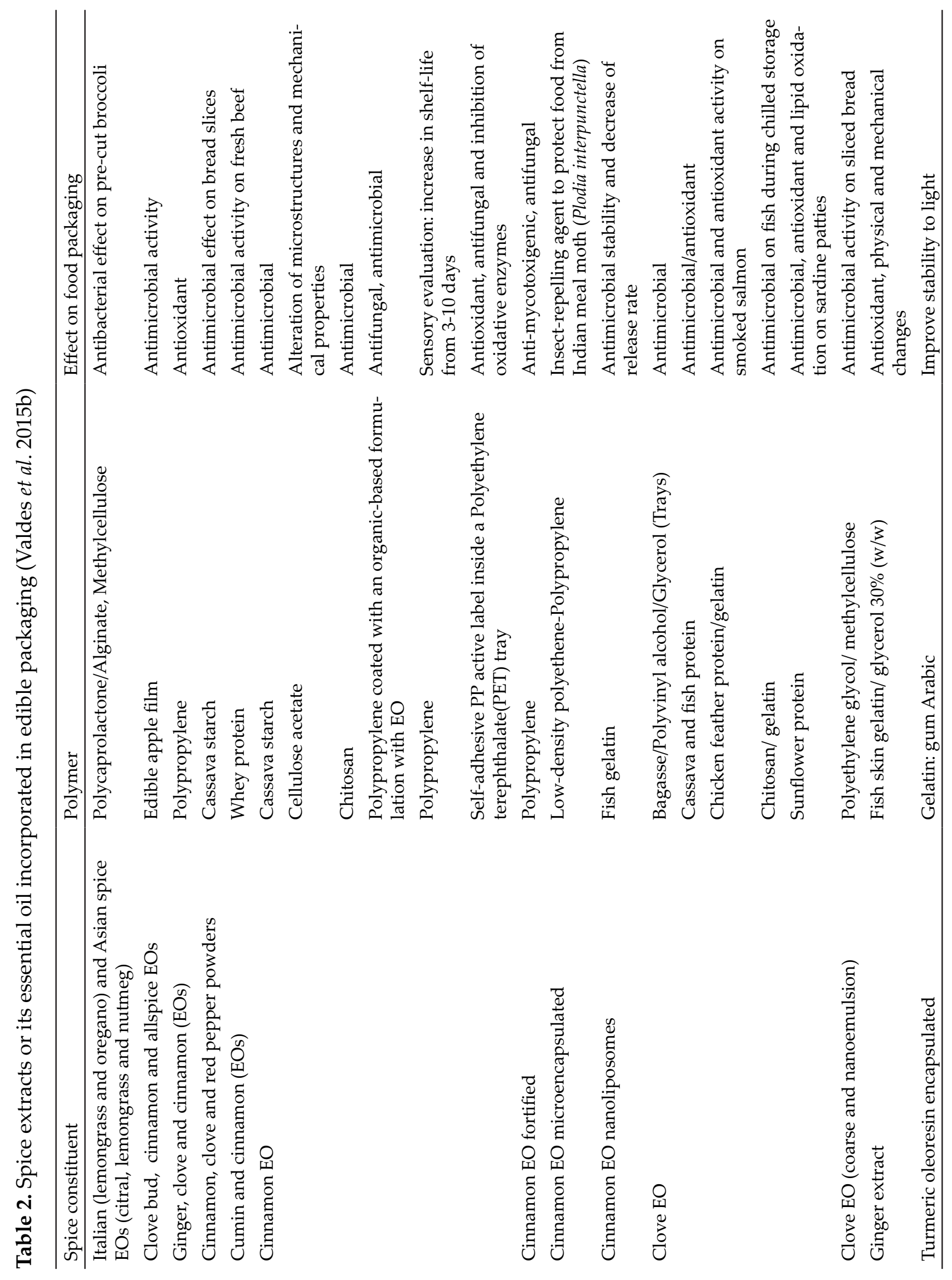


Table 3. Use ofspice essential oils as natural antimicrobials in edible packaging (Sanchez-Gonzalez et al. 2011)

\begin{tabular}{llll}
\hline Food group & Food & Essential oil & Microorganisms \\
\hline Cereals & Maize grain & Thyme, Clove, Anise & Aspergillus \\
Dairy & Mozzarella cheese & Clove & Listeria monocytogenes \\
Fish & Mediterranean swordfish fillet & Thyme & Natural flora \\
& Salmon fillet/cod fillet & Oregano & Photobacterium phosphoreum \\
Fruit & Strawberry & Thyme & Rhizopus, Botrytis \\
& Peach & & Rhizopus, Penicillium \\
Meat & Mortadella (bologna-type sausage) & Thyme, Rosemary & Natural flora \\
& Minced mutton & Clove & Listeria monocytogenes \\
& Minced beef & Oregano & Natural flora \\
& & Thyme & Escherichia coli \\
& Hot dog & Thyme, Clove & Listeria monocytogenes \\
& Cooked chicken sausage & Mustard & Escherichia coli \\
Vegetables & Teef fillet & Oregano & Listeria monocytogenes \\
& Tomato paste & Thyme, Clove & Aspergillus \\
& Lettuce & Oregano & Natural flora \\
& Eggplant salad & Oregano & Escherichia coli O157:H7 \\
& Carrot & Thyme & Natural flora \\
\hline
\end{tabular}

displayed the lowest weight loss values and it could control variations in the physico-chemical properties such as hardness, water activity and colour. It preserved the microbiological characteristics and sensory quality of the double cream cheese after 42 days of storage at $5^{\circ} \mathrm{C}$ (Molina-Hernandez et al. 2020).

Alginate film incorporated with garlic essential oil has a significant inhibitory effect on $B$. cereus and Staphylococcus aureus (Pranoto et al. 2005). Chitosan film incorporated with nanoencapsulated garlic essential oil $(2 \% \mathrm{v} / \mathrm{v})$ exhibited the peroxide value, thiobarbituric acid reactive substances, aerobic plate count of $0.37 \mathrm{meq} / \mathrm{kg}$ lipid, $0.47 \mathrm{mg}$ malondialdehyde/ $\mathrm{kg}$ and $3.69 \mathrm{log}$ CFU/g at the end of $50^{\text {th }}$ day of vacuum-packed sausages and it has no significant differences in the sensory properties (Esmaeili et al. 2020).

Chitosan film incorporated with ginger oil inhibited the growth of E. coli in chicken meat due to the active components in ginger (shogaol and gingerol) (Irawan et al. 2017).

\section{Rosemary extract}

Nanoemulsion based gelatin and chitosan coating fused with a mixture of rosemary extract and $\varepsilon$-poly-L-lysine ( $\varepsilon-\mathrm{PL})$ exhibited the lowest total viable bacterial counts (TVC), mould and yeast counts and thiobarbituric acid reactive substance (TBARS) values under $4^{\circ} \mathrm{C}$ refrigeration over 16 days in ready-to-eat carbonado chicken (Huang et al. 2020).

\section{Star anise essential oil}

Nanoemulsion prepared with soy protein isolate (SPI), polylysine, nisin and star anise essential oil showed good stability and better antimicrobial effect in ready-to-eat Yao meat products for 45 days. Nanoemulsion based edible coating has no effect on the moisture content of the meat samples for 20 days and shelf-life was extended from 8 to 16 days with good retention of colour and odour (Liu et al.2020). Whey protein edible film incorporated with anise essential oil at $4 \%$ (v/v) exhibited antimicrobial activity against major moulds (Aspergillus flavus, Penicillium sp.) 
found on dried fish (Decapterus maruadsi) and shelf-life was extended up to 21 days at $30^{\circ} \mathrm{C}$ (Matan 2012).

\section{Tarragon essential oil}

Incorporation of nano-encapsulated (NP) tarragon essential oils (TEO) in the chitosangelatin edible coating could extend the shelf-life of fresh pork slice by eight days and also resulted in an improved antioxidant, antibacterial and sensory properties (Zhang et al. 2020).

\section{Thyme oil}

Thyme essential oil incorporated starch-gellan films exhibited antifungal activity against Botryotinia fuckeliana and Alternaria alternata. To control the loss of essential oil, lecithin was encapsulated in the starch-gellan film (Sapper et al. 2018).

\section{Toxicological effects of some spice constituents}

Estragole in the essential oil of Ocimum basilicum exhibited carcinogenic property in rats and mice (Miller et al. 1983; Anthony et al. 1987). Toxic effects of bioactive compounds such as carvacrol, thymol, cinnamaldehyde and carvone was observed at cellular level (Stammati et al. 1999). Ginger has some minor antagonistic effect. In a clinical study, 12 healthy volunteers were given $400 \mathrm{mg}$ of ginger orally for two week (3 times/day). In initial 2 days, mild diarrhoea was observed while dosage greater than $6 \mathrm{~g}$ can cause gastric irritant (Ali et al. 2008). Safrole present in black pepper, cinnamon and nutmeg is identified as a weak hepatocarcinogen. It can be related to formation of safrole DNA adducts (Liu et al. 1999). Aydin et al. (2005) noted that thymol and $\gamma$-terpinene when used at concentration higher than $0.2 \mathrm{mM}$ induced DNA damage. Carvacrol induced DNA damage at a concentration of $0.01 \mathrm{mM}$, where it is non-toxic at concentration $<0.05 \mathrm{mM}$. Hence essential oils at lower concentration have higher beneficial effects whereas higher concentration may cause serious toxicological effects and allergic reactions.

\section{Advantages of spice edible packaging}

Spices and its essential oil contains volatile constituents which are mainly responsible for health benefits such as antimicrobial, digestive stimulant, antioxidant, anti-inflammatory activites (Kulisic et al. 2004). Decrease in the diffusion rate of antimicrobial compound of spice essential oil was observed in edible packaging. Thus higher concentration of active compound was seen on product surface. Hence it reduced microbial contamination and extended the shelf-life of product (Quintavalla et al. 2002; Kristo et al. 2008).

\section{Limitations of edible packaging}

The commercial use of edible films and coatings has many limiting factors such as the complexity of the production process and the huge investment necessary to install new film production or coating equipment (Han 2014). The other limitations are while labelling the final product food manufacturers should include all the ingredients used in film formation on their label and no-objection notifications have to be obtained by edible film and coating material suppliers (Han 2001; Han 2002; Krochta 2002). Laboratory-scale film making methods cannot make large-sized edible films $(>25 \mathrm{~cm})$ and it also takes very long drying time (2-3 days) and error in thickness control. Hence, it is unbefitting for ind ustrial scaleup. It is necessary to develop a continuous film making equipment with high production rate and low production time for making a scaled-up production (Zhang et al. 2014). Essential oils are incorporated in edible films to improve the antimicrobial properties because essential oils are generally regarded as safe (GRAS). A major limitation in the usage of spice essential oil as a food preservative is their aroma which affects the organoleptic characteristics of the food product. By trained individuals or by using instrumental analysis, sensory tests need to be carried out to meet product acceptance and customer satisfaction (Sanchez-Gonzalez et al. 2011). Gutierrez et al. (2009) reported that ready-to-eat lettuce and carrot treated with thyme and oregano essential oil was rejected at the end of storage due to development of strong aroma of the spices at sensory test. While drying the edible film, significant loss of volatile compounds occur. The low stability and volatility of spice essential oil 
against light and gaseous concentration during processing and storage limit their usage as a preservative. Micro and nano-encapsulation results in the controlled release of EOs onto food surfaces and also increases the film stability against environmental factors (SanchezGonzalez et al. 2011).

\section{Conclusion}

Environmental issues caused by the usage of plastic packaging are the accumulation of plastic wastage on land which reduces soil fertility, emits hazardous volatile organic compounds during incineration etc. Considering these environmental effects and to reduce the plastic usage, edible packaging of food has been developed. The spices contain various bioactives like flavonoids, terpenoids and polyphenol. The incorporation of spices or essential oil in edible packaging exert antioxidant, antimicrobial activity and also extend the shelf-life of the product. Spice bioactives also replaces the usage of synthetic preservatives in food. However, in comparison with plastic packaging materials, edible packaging materials are highly sensitive to water, permeable to gaseous concentration and unstable thermally and mechanically. These negative effects have an impact on the scaling-up of edible packaging. Laboratoryscale production of edible packaging has some disadvantages which should be addressed before industrial level production. Therefore, further research should be carried out on edible packaging to facilitate their large-scale production and utilization as packaging material.

\section{Acknowledgement}

The authors thank the Director, CSIR-CFTRI, Mysuru for a keen interest in this work.

\section{References}

Abdou E S, Galhoum G F \& Mohamed E N 2018 Curcumin loaded nanoemulsions/pectin coatings for refrigerated chicken fillets. Food hydrocoll. 83: 445-453.

Ali B H, Blunden G, Tanira M O \& Nemmar A 2008 Some phytochemical, pharmacological and toxicological properties of ginger (Zingiber officinale Roscoe): A review of recent research. Food Chem.Toxicol. 46: 409-420.

Almasi H, Ghanbarzadeh B \& Entezami A A 2010 Physicochemical properties of starch-CMCnanoclay biodegradable films. Int. J. Biol. Macromol. 46: 1-5.

Anthony A, Caldwell G, Hutt A G \& Smith R L 1987 Metabolism of estragole in rat and mouse and influence of dose size on excretion of the proximate carcinogen 10 -hydroxyestragole. Food Chem. Toxicol. 25: 799-806.

Arshad H, Mohsin Ali T \& Hasnain A 2020 Bioactive properties and oxidative stability of nutmeg oleoresin microencapsulated by freeze drying using native and OSA sorghum starches as wall materials. J. Food Meas. Charact. 14: 2559-2569.

Avila-Sosa R, Palou E, Munguia M T J, NevarezMoorillon G V, Cruz A R N \& Lopez-Malo A 2012 Antifungal activity by vapor contact of essential oils added to amaranth, chitosan, or starch edible films. Int. J. Food Microbiol. 153: 66-72.

Aydin S, Basaran A A \& Basaran N 2005 The effects of thyme volatiles on the induction of DNA damage by the heterocyclic amine IQ and mitomycin C. Mutat. Res. Genet. Toxicol. Environ. Mutagen. 581: 43-53.

Ayoughi F, Marzegar M, Sahari M A \& Naghdibadi H 2011 Chemical compositions of essential oils of Artemisia dracunculus L. and endemic Matricaria chamomilla L. and an evaluation of their antioxidative effects. J. Agr. Sci. Tech.13: 79-88.

Bahram S, Rezaei M, Soltani M, Kamali A, Ojagh S M \& Abdollahi M 2014 Whey protein concentrate edible film activated with cinnamon essential oil. J. Food Process. Preserv. 38: 1251-1258.

Basilico M Z \& Basilico J C 1999 Inhibitory effects of some spice essential oils on Aspergillus ochraceus NRRL 3174 growth and ochratoxin A production. Lett. Appl. Microbiol. 29: 238-241.

Behbahani B A, Shahidi F, Yazdi T F, Mortazavi S A \& Mohebbi M 2017 Antioxidant activity and antimicrobial effect of tarragon (Artemisia dracunculus) extract and chemical composition of its essential oil. J. Food Meas. Charact. 11: 847-863. 
Beltran J M G \& Esteban M A 2016 Properties and applications of plants of Origanum sp. Genus. SM. J. Biol. 2: 1-9.

Bolumar T, Andersen M L \& Orlien V 2011 Antioxidant active packaging for chicken meat processed by high pressure treatment. Food Chem. 129: 1406-1412.

Bourtoom T 2008 Factors affecting the properties of edible film prepared from mung bean proteins. Int. Food Res. J. 15: 167-180.

Burt S A, Vlielander R, Haaqsman H P \& Veldhuizen E J 2005 Increase in activity of essential oil components carvacrol and thymol against Escherichia coli O157:H7 by addition of food stabilizers. J. Food Prot. 68: 919-926.

Chaleshtori R S, Rokni N, Razavilar V \& Kopaei M R 2013 The evaluation of the antibacterial and antioxidant activity of tarragon (Artemisia dracunculus L.) essential oil and its chemical composition. Jundishapur J. Microbiol. 6: 78-77.

Chandra M C, Harini K, Sudharsan K, Radha Krishnan K \& Sukumar M 2019 Quorum quenching effect and kinetics of active compound from S. aromaticum and C. cassia fused packaging films in shelf life of chicken meat. LWT-Food Sci. Technol. 105: 87-102.

Chandra M C, Radha Krishnan K, Babuskin S, Sudharsan K, VajihaAafrin, Lalithapriya U, Mariyajenita P, Harini K, Madhushalini D \& Sukumar M 2017 Active compound diffusivity of particle size reduced S. aromaticum and C. cassia fused starch edible films and the shelf life of mutton (Capra aegagrushircus) meat. Meat Sci. 128: 47-59.

Chandra Mohan C, Rakhavan K R, Sudharsan K, Radhakrishnan K, Babuskin S \& Sukumar M 2016 Design and characterization of spice fused tamarind starch edible packaging films. LWT-Food Sci. Technol. 68: 642-652.

Dalanche F, Carvalho C Y, Alves V D, MoldaoMrtins M \& Mata P 2016 Optimisation of gellan gum edible coating for ready-to-eat mango (Mangifera indica L.) bars. Int. J. Biol. Macromol. 84: 43-53.

Denavi G, Tapia-Blacido D R, Anon M C, Sobral P J A, Mauri A N \& Menegalli F C 2009 Effects of drying conditions on some physical properties of soy protein films. J. Food Eng. 90: 341-349.

Derakhshan S, Sattari M \& Bigedli M 2007 Evaluation of antibacterial activity and biofilm formation in Klebsiella pneumoniae in contact with essential oil and alcoholic extract of cumin seed (Cuminum cyminum). Int. J. Antimicrob. Agents 29: S601.

Diab T, Biliaderis C G, Gerasopoulos D \& Sfakiotakis E 2001 Physicochemical properties and application of pullulan edible films and coatings in fruit preservation. J. Sci. Food Agric. 81: 988-1000.

Diao W R, Hu Q P, Zhang H \& Xu J G 2014 Chemical composition, antibacterial activity and mechanism of action of essential oil from seeds of fennel (Foeniculum vulgare Mill.). Food Control 35: 109-116.

Du W X, Olsen C W, Avena-Bustillos R J, McHugh T H, Levin C E \& Friedman M 2009 Effects of allspice, cinnamon, and clove bud essential oils in edible apple films on physical properties and antimicrobial activities. J. Food Sci. 74: M372-M378.

El-Baroty G S, Abd El-Baky H H, Farag R S \& Saleh M A 2010 Characterization of antioxidant and antimicrobial compounds of cinnamon and ginger essential oils. Afr. J. Biochem. Res. 4: 167-174.

Esmaeili H, Cheraghi N, Khanjari A, Rezaeigolestani M, Basti A A, 1 Kamkar A \& Aghaee E M 2020 Incorporation of nanoencapsulated garlic essential oil into edible films: Anovel approach for extending shelf life of vacuum-packed sausages. Meat Sci. 166: 108-135.

Espitia P J P, Du W X, Avena-Bustillos R D J, Soares N D F F \& Mc Hugh T H 2014 Optimal antimicrobial formulation and physicalmechanical properties of edible films based on Acai and pectin for food preservation. Food Hydrocoll. 2: 38-49.

Fabra M J, Talens P \& Chiralt A 2010 Influence of calcium on tensile, optical and water vapour permeability properties of sodium caseinate edible films. J. Food Eng. 96: 356-364.

FICCI (Federation of Indian Chambers of Commerce \& Industry) 2016 A report on plastic industry. $2^{\text {nd }}$ National Conference: Plastic packagingthe sustainable choice. http://ficci.in/ 
spdocument/20690/plastic-packaging-report. pdf.

Freitas I R, Cortez-Vega W R, Pizato S, PrenticeHernandez C \& Borges C D 2013 Xanthan gum as a carrier of preservative agents and calcium chloride applied on fresh-cut apple. J. Food Saf. 33: 229-238.

Froiio F, Mosaddik A, Morshed M T, Paolino D, Fessi H \& Elaissari A 2019 Edible polymers for essential oils encapsulation: application in food preservation. Ind. Eng. Chem. Res. 58: 20932-20945.

Georgantelis D, Ambrosiadis I, Katikou P, Blekas G \& Georgakis S A 2007 Effect of rosemary extract, chitosan and $\alpha$-tocopherol on microbiological parameters and lipid oxidation of fresh pork sausages stored at $4^{\circ} \mathrm{C}$. Meat Sci. 76: 172-181.

Ghasemi G, Fattahi M, Alirezalu A \& Ghosta Y 2018 Antioxidant and antifungal activities of a new chemovar of cumin (Cuminum cyminum L.). Food Sci. Biotechnol. 28: 669-677.

Ghosh T, Monika \& Vimal Katiyar V 2020 Emerging sustainable nanostructured materials facilitated by herbal bioactive agents for edible food packaging. Nano-food Eng.1: 259-287.

Gomez-Estaca J, Lopez-de-Dicastillo C, HernandezMunoz P, Catala R \& Gavara R 2014 Advances in antioxidant active food packaging. Trends Food Sci. Technol. 35: 42-51.

Guldiken B, Ozkan G, Catalkaya G, Ceylan F D, Yalcinkaya I E \& Capanoglu E 2018 Phytochemicals of herbs and spices: health versus toxicological effects. Food Chem. Toxicol. 119: 37-49.

Gupta A D, Bansal V K, Babu V \& Maithi N 2013 Chemistry, antioxidant and antimicrobial potential of nutmeg (Myristica fragrans Houtt). J. Genet. Eng. Biot. 11: 25-31.

Gutierrez J, Bourke P, Lonchamp J \& Barry-Ryan C 2009 Impact of plant essential oils on morphological, organoleptic and quality markers of minimally processed vegetables. Innov. Food Sci. Emerg. Technol. 10: 195-202.

Han J H 2001 Design of edible and biodegradable films/coatings containing active ingredients. In: Park H J, Testin R F, Chinnan M S, Park J W (Eds.) Active biopolymer films and coatings for food and biotechnological uses (pp.187198). Proceedings of Precongress Short Course of IUFoST, Seoul, Korea.

Han J H 2002 Protein-Based Films and Coatings carrying antimicrobial agents. In: Gennadios A (Ed) Protein-based films and coatings (pp: 485-499). CRC Press, Boca Raton.

Han J H 2014 Edible Films and Coatings: A Review. In: Innovations in Food Packaging (Ed) (pp: 213-255). A volume in food science and technology, PepsiCo Corporate R\&D/PepsiCo Advanced Research, Plano, TX, USA.

Harlina P W, Ma M, Shahzad R, Gouda M M \& Qiu N 2018 Effect of clove extract on lipid oxidation, antioxidant activity, volatile compounds and fatty acid composition of salted duck eggs. J. Food Sci. Technol. 55: N4719-4734.

Hassani F, Garousi F \& Javanmard M 2012 Edible coating based on whey protein concetratericebran oil to maintain the physical and chemical properties of the kiwifruit (Actinida deliciosa). Trakia. J. Sci. 10: 26-34.

Huang M, Wang H, Xu X, Lu X, Song X \& Zhou G 2020 Effects of nanoemulsion-based edible coatings with composite mixture of rosemary extract and $\varepsilon$-poly-L-lysine on the shelf life of ready-to-eat carbonado chicken. Food Hydrocoll. 102: 105576.

Huber K C \& Embuscado M 2009 Edible films and coatings for food applications.10.1007/978-0-387-92824-1.

Hussain A I, Anwar F, Sherazi S T H \& Przybylski R 2008 Chemical composition, antioxidant and antimicrobial activities of basil (Ocimum basilicum) essential oils depends on seasonal variations. Food Chem. 108: 986-995.

Irawan A, Barleany D R, Jayanudin J, MeriYulvianti D \& Haqi F 2017 Antimicrobial activity of chitosan based edible film enriched with red ginger essential oil as an active packaging for food. Res. J. Pharm. Biol. Chem Sci. 8: 1523-1530.

Jeevahan J, Chandrasekaran M, Durairaj R B, Mageshwaran G \& Joseph G B 2017 A brief review on edible food packing materials. J. Global Eng. Problems Solutions 1: 9-19.

Jongjareonrak A, Benjaku S, Visessangua W, Prodpra 
T \& Tanaka M 2006 Characterization of edible films from skin gelatin of brownstripe red snapper and bigeye snapper. Food Hydrocoll. 20: $492-501$.

Kaefer C M \& Milner J A 2008 The role of herbs and spices in cancer prevention. J. Nutr. Biochem. 19: 347-361.

Kanmani P \& Lim S T 2013 Development and characterization of novel probiotic-residing pullulan/starch edible films. Food Chem. 141: 1041-1049.

Karbowiak T, Debeaufort F, Champion D \& Voilley A 2006 Wetting properties at the surface of iotacarrageenan-based edible films. J. Colloid Interface Sci. 294: 400-410.

Karunamay S, Badhe S R, Shulka V \& Jaiswal S 2020 Effect of essential oil of clove and oregano treated edible packaging film in extending the shelf life of paneer. Pharm. Inno. J. 9: 317-322.

Kavoosi G, Dadfar S M M, Mohammadi Purfard A \& Mehrabi R 2013 Antioxidant and antibacterial properties of gelatin films incorporated with carvacrol. J. Food Safe. 33: 423-432.

Ket-On A, Pongmongkol N, Somwangthanaroj A, Janjarasskul T \& Tananuwong K 2016 Properties and storage stability of whey protein edible film with spice powders. J. Food Sci. Technol. 53: 2933-2942.

KhanMR, SadiqMB \& Mehmood Z2020Development of edible gelatin composite films enriched with polyphenol loaded nanoemulsions as chicken meat packaging material. CYTA-J. Food. 18: 137-146.

Kodera Y, Ushijima M, Amano H, Suzuki J \& Matsutomo T 2017 Chemical and biological properties of S-1-propenyl-1-cysteine in aged garlic extract. Molecules. 22: 570-588.

Krishnan R K, Babuskin S, Azhagu S B P, Sasikala M, Sabina K, Archana G \& Sukumar M 2014 Antimicrobial and antioxidant effects of spice extracts on the shelf life extension of raw chicken meat. Int. J. Food Microbiol. 171: 32-40.

Kristo E, Koutsoumanis K P \& Biliaderis C G 2008 Thermal, mechanical and water vapor barrier properties of sodium caseinate films containing antimicrobials and their inhibitory action on Listeria monocytogenes. Food Hydrocoll. 22: 373-386.

Krochta J M 2002 Proteins as raw material for films and coatings: definition, current status and oppurtunities. In: Gennadios A (Ed.) Proteinbased films and coatings (pp:1-41). CRC Press, Boca Raton.

Kulisic T, Radonic A, Katalinic V \& Milos M 2004 Use of different methods for testing activity of oregano essential oil. Food Chem. 85: 633-640.

Lanzotti V, Scala F \& Bonanomi G 2014 Compounds from allium species with cytotoxic and antimicrobial activity. Phytochem. Rev. 13: 769-791.

Lee K G \& Shibamoto T 2001 Antioxidant property of aroma extract isolated from clove buds [Syzygium aromaticum (L.) Merr. et Perry]. Food Chem. 74: 443-448.

Lee K Y, Shim J \& Lee H G 2004 Mechanical properties of gellan and gelatin composite films. Carbohyd. Polym. 56: 251-254.

Lee S J, Umano K, Shibamoto T, Lee K G 2005 Identification of volatile components in basil (Ocimum basilicum L.) and thyme leaves (Thymus vulgaris L.) and their antioxidant properties. Food Chem. 91: 131-137.

Li T, Hu W, Li J, Zhang X, Zhu J \& Li X 2012 Coating effects of tea polyphenol and rosemary extract combined with chitosan on the storage quality of large yellow croaker (Pseudosciaena crocea). Food Control. 25: 101-106.

Liu L, Liu C K, Fishman M L \& Hicks K B 2007 composite films from pectin and fish skin gelatin or soybean flour protein. J. Agric. Food Chem. 55: 2349-2355.

Liu Q, Zhang M, Bhandari B, Xu J \& Chaohui Yang 2020 Effects of nanoemulsion-based active coatings with composite mixture of star anise essential oil, polylysine, and nisin on the quality and shelf life of ready-to-eat yaomeat products. Food Control. 107: 106771-106778.

Liu TY, Chen CC , Chen CL \& Chi CW 1999 Safroleinduced oxidative damage in the liver of spragudawley rats. Food Chem. Toxicol. 37: 697-702.

Mahfoudhi N \& Hamdi S 2015 Use of almond gum and gum arabic as novel edible coating to 
delay postharvest ripening and to maintain sweet cherry (Prunus avium) quality during storage. J. Food Process. Preserv. 39: 1499-1508.

Mamtani K 2017 Edible packaging market by material (lipids, polysaccharides, proteins, surfactants, and composite films), and end users (food $\&$ beverages and pharmaceuticals)-global opportunity analysis and industry forecast, 2017-2023. Allied Market Research. pp:138.

Manasa D, Srinivas P \& Sowbhagya H B 2013 Enzyme-assisted extraction of bioactive compounds from ginger (Zingiber officinale Roscoe). Food Chem. 139: 509-514.

Mansingh D P, Dalpati N, Sali V K \& Vasanthi A H R 2018 Alliin the precursor of allicin in garlic extract mitigates proliferation of gastric adenocarcinoma cells by modulating apoptosis. Pharmacogn. Mag. 14: 84-91.

Manzanarez-Lopez F, Soto-Valdez H, Auras R \& Peralta E 2011 Release of $\alpha$-Tocopherol from Poly (lactic acid) films, and its effect on the oxidative stability of soybean oil. J. Food Eng. 104: 508-517.

Maqbool M, Ali A, Alderson P G, Mohamed M T M, Siddiqui Y \& Zahid N 2011 Postharvest application of gum arabic and essential oils for controlling anthracnose and quality of banana and papaya during cold storage. Postharvest Biol. Technol. 62: 71-76.

Marino M, Bersani C \& Comi G 1999 Antimicrobial activity of the essential oils of Thymus vulgaris L. measured using a bioimpedometric method. J. Food Prot. 62: 1017-1023.

Matan N 2012 Antimicrobial activity of edible film incorporated with essential oils to preserve dried fish (Decapterus maruadsi). Int. Food Res. J. 19: 1733-1738.

Meena M R \& Sethi V 1994 Antimicrobial activity of essential oils from spices. J. Food Sci. Technol. 31: 68-70.

Meloa E D A, Filhob M J \& Guerra N B 2005 Characterization of antioxidant compounds in aqueous coriander extract (Coriandrum sativum L.). LWT-Food Sci. Technol. 38: 15-19.

Miller E C, Swanson A B, Phillips D H, Fletcher T L, Liem A \& Miller J A 1983 Structure-activity studies of the carcinogenicities in the mouse and rat of some naturally occurring and synthetic alkenylbenzene derivatives related to safrole and estragole. Cancer Res. 43: 1124-1134.

Molina-Hernandez J B, Echeverri-Castro A, MartinezCorrea H A \& Andrade-Mahecha M M 2020 Edible coating based on achira starch containing garlic/oregano oils to extend the shelf life of double cream cheese. Rev. Fac. Nac. Agron. Medellin. 73: 9099-9108.

Naeem A, Abbas T, Mohsin Ali T \& Hasnain A 2019 Application of guar gum-based edible coatings supplemented with spice extracts to extend post-harvest shelf life of lemon (Citrus limon). Qual. Assur. Saf. Crop. Foods.11: 241-250.

Nagella P, Thiruvengadam M, Ahmad A, Yoon J Y \& Chung I M 2014 Composition of polyphenols and antioxidant activity of garlic bulbs collected from different locations of Korea. Asian J. Chem. 26: 897-902.

Nakai M, Harada M, Akimoto K, Shibata H, Miki W \& Kiso Y 2003 Novel antioxidative metabolites in rat liver with ingested sesamin. J. Agric. Food Chem. 51: 1666-1670.

Nayik G A, Majid I \& Kumar V 2015 Developments in edible films and coatings for the extension of shelf life of fresh fruits. Am. J. Nutrition Food Sci. 2: 16-20.

Negi PS 2012 Plant extracts for the control of bacterial growth: efficacy, stability and safety issues for food application. Int. J. Food Microbiol. 156: 7-17.

Olivasa G I \& Barbosa-Canovas G V 2008 Alginatecalcium films: Water vapor permeability and mechanical properties as affected by plasticizer and relative humidity. LWT-Food Sci. Technol. 41: 359-366.

Oses J, Fabregat-Vazquez M, Pedroza-Islas R, Tomas S A, Cruz-Orea A \& Mate J I 2009 Development and characterization of composite edible films based on whey protein isolate and mesquite gum. J. Food Eng. 92: 56-62.

Pranoto Y, Salokhe V M \& Rakshit S K 2005 Physical and antibacterial properties of alginate-based edible film incorporated with garlic oil. Food Res. Int. 38: 267-272.

Prasad S \& Tyagi A K 2015 Ginger and its 
constituents: role in prevention and treatment of gastrointestinal cancer. Gastroent. Res. Pract. 2015: 1-11.

Priyadarshi S, Harohally N V, Roopavathi C \& Naidu M M 2018. Isolation, identification, structural elucidation and bioactivity of Heneicos-1-ene from Coriandrum sativum L. foliage. Sci. Rep. 8: $1-6$.

Quintavalla S \& Vicini L 2002 Antimicrobial food packaging in food industry. Meat Sci. 62: 373-380.

Radhakrishnan K, Babuskin S, Rakhavan K R, Tharavin R, Babu A S P, Sivarajan M \& Sukumar M 2015 Potential application of corn starch edible films with spice essential oils for the shelf life extension of red meat. J. Appl. Microbiol. 119: 1613-1623.

Ramos M, Jimenez A, Peltzer M \& Garrigos M C 2014 Development of novel nano-biocomposite antioxidant films based on poly (lactic acid) and thymol for active packaging. Food Chem. 162: 149-155.

Razavi S M A, Mohammad A \& Zahedi A Y 2015 Characterisation of a new biodegradable edible film based on sage seed gum: Influence of plasticiser type and concentration. Food Hydrocoll. 43: 290-298.

Sabato S F, Ouattara B, Yu H, Aprano G D, Le Tien C, Mateescu M A \& Lacroix M 2001 Mechanical and barrier properties of cross-linked soy and whey protein based films. J. Agric. Food Chem. 49: 1397-1403.

Sacchetti G, Maietti S, Muzzoli M, Scaglianti M, Manfredini S \& Radice M 2005 Comparative evaluation of 11 essential oils of different origin as functional antioxidants, antiradicals, and antimicrobials in foods. Food Chem. 91: 621-632.

Salgado P R, Lopez-Caballero M E, Gomez-Guillen M C, Mauri A N \& Montero M P 2013 Sunflower protein films incorporated with clove essential oil have potential application for the preservation of fish patties. Food Hydrocoll. 33: 74-84.

Sanchez-Gonzalez L, Vargas M, Gonzalez- Martinez C, Chiralt A \& Chafer M 2011 Use of essential oil in bioactive edible coatings. Food Eng. Rev. 3: 1-16.
Sapper M, Wilcaso P, Santamarina M P, Rosello J \& Chiralt A 2018 Antifungal and functional properties of starch-gellan films containing thyme (Thymus zygis) essential oil. Food Control. 92: 505-515.

Sauceda-Pompa S, Jasso-Cantu D, Ventura-Sobrevilla J, Saenz-Galindo A, Rodriguez-Herrera R \& Aguilar C N 2007 Effect of candelilla wax with natural antioxidants on the shelf life quality of fresh-cut fruits. J. Food Qual. 30: 823-836.

Senatore F, Oliviero F, Scandolera E, TaglialatelaScafati O, Roscigno G, Massimo Zaccardelli M \& Falco E D 2013 Chemical composition, antimicrobial and antioxidant activities of anethole-rich oil from leaves of selected varieties of fennel [Foeniculum vulgare Mill. ssp. vulgare var. azoricum (Mill.) Thell]. Fitoterapia. 90: 214-219.

Shahat A A, Ibrahim A Y, Hendawy S F, Omer E A, Hammouda F M, Abdel- Rahman F H \& Saleh M A2011 Chemical composition, antimicrobial and antioxidant activities of essential oils from organically cultivated fennel cultivars. Molecules. 16: 1366-1377.

Shan B, Cai Y Z, Brooks J D \& Corke H 2007 Antibacterial properties and major bioactive components of cinnamon stick (Cinnamomum burmannii): activity against foodborne pathogenic bacteria. J. Agric. Food Chem. 55: 5484-5490.

Silva-Weiss A, Ihl M, Sobral P J A, Gomez-Guillen MC \& Bifani V 2013 Natural additives in bioactive edible films and coatings: functionality and applications in foods. Food Eng. Rev. 5: 200-216.

Skurtys O, Velasquez P, Henriquez O, Matiacevich S, Enrione J \& Osorio F 2011 Wetting behavior of chitosan solutions on blueberry epicarp with or without epicuticular waxes. LWT-Food Sci. Technol. 44: 1449-1457.

Soylu S, Yigitbas H, Soylu E M \& Kurt S 2007 Antifungal effects of essential oils from oregano and fennel on Sclerotinia sclerotiorum. J. Appl. Microbiol. 103: 1021-1030.

Spencer A 2018 Have your food and eat the wrapper too. Food Tank (The Think Tank for Food). https://foodtank.com/news/2018/09/haveyour-food-and-eat-the-wrapper-too/ 
Stammati A, Bonsi P, Zucco F, Moezelaar R, Alakomi H L \& Wright A V 1999 Toxicity of selected plant volatiles in microbial and mammalian short-term assays. Food Chem. Toxicol. 37: 813-823.

Tajkarimi M M, Ibrahim S A \& Cliver D O 2010 Antimicrobial herb and spice compounds in food. Food Control. 21: 1199-1218.

Teixeira B, Marques A, Pires C, Ramos C, Batista I, Saraiva J A \& Nunes M L 2014 Characterization of fish protein films incorporated with essential oils of clove, garlic and origanum: physical, antioxidant and antibacterial properties. LWTFood Sci. Technol. 59: 533-539.

Tongnuanchan P, Benjakul S \& Prodpran T 2013 Physico-chemical properties, morphology and antioxidant activity of film from fish skin gelatin incorporated with root essential oils. J. Food Eng. 117: 350-360.

Valdes A, Burgos N, Jimenez A \& Garrigos M C 2015a Natural pectin polysaccharides as edible coatings. Coatings. 5: 865-886.

Valdes A, Mellinas AC, Ramos M, Burgos N, Jimenez A \& Garrigos M C 2015b Use of herbs, spices and their bioactive compounds in active food packaging. RSC Adv. 50: 4034-4035.

Vallverdu-Queralt A, Regueiro J, Martinez-Huelamo M, Rinaldi-Alvarenga J F, Leal L N \& LamuelaRaventos R M 2014 A comprehensive study on the phenolic profile of widely used culinary herbs and spices: rosemary, thyme, oregano, cinnamon, cumin and bay. Food Chem. 154: 299-307.

Vargas M, Albors A \& Chiralt A 2011 Application of chitosan-sunflower oil edible films to pork meat hamburgers. Ital. Oral Surg. 1: 39-43.
Wagh Y R, Pushpadass H A, Emerald F M E \& Nath B S 2014 Preparation and characterization of milk protein films and their application for packaging of Cheddar cheese. J. Food Sci. Technol. 51: 3767-3775.

Wang G W, Hu W T, Huang B K \& Qin L P 2011 Illicium verum: A review on its botany, traditional use, chemistry and pharmacology. J. Ethnopharmacol. 136: 10-20.

Wu J, Liu H, Ge S, Wang S, Qin Z, Chen L, Zheng Q, Liu Q \& Zhang Q 2015 The preparation, characterization, antimicrobial stability and in vitro release evaluation of fish gelatin films incorporated with cinnamon essential oil nanoliposomes. Food Hydrocoll. 43: 427-435.

Yoo M, Lee S, Kim S, Hwang J B, Choe J \& Shin D 2014 Composition of organosulfur compounds from cooland warm-type garlic (Allium sativum L.) in Korea. Food Sci. Biotechnol. 23: 337-344.

Zengin H \& Baysal A H 2015 Antioxidant and antimicrobial activities of thyme and clove essential oils and application in minced beef. J. Food Process. Preserv. 39: 1261-1271.

Zhang S, Gu W, Cheng Z, Ying Li Y \& Gu W 2014 Development of edible packaging materials. Adv. Mater. Res. 904: 189-191.

Zhang G, Yuan C \& Sun Y 2018 Effect of selective encapsulation of hydroxypropyl- $\beta$ cyclodextrin on Components and antibacterial properties of star anise essential oil. Molecules. 23: 11-26.

Zhang H, Liang Y, Li X \& Kang H 2020 Effect of chitosan-gelatin coating containing nanoencapsulated tarragon essential oil on the preservation of pork slices. Meat Sci. 166: 108-137 